\title{
Aplikasi Penentuan Tunjangan Kinerja dan Rekomendasi Pegawai Universitas Singaperbangsa Karawang
}

\author{
Aldi Jakaria, Ade Andri Hendriadi, Nina Sulistiyowati \\ Fakultas ilmu komputer, Program Studi Teknik Informatika, Universitas Singaperbangsa Karawang, Karawang, Indonesia \\ Email: ${ }^{1}$ aldi.jakaria@ student.unsika.ac.id, ${ }^{2}$ ade.andri@ staff.unsika.ac.id, ${ }^{3}$ nina.sulistio@ unsika.ac.id
}

\begin{abstract}
Abstrak
Universitas Singaperbangsa Karawang belum memiliki sistem dan kriteria penilain kinerja pegawai non-P3K. Saat ini biro kepegawaian di lingkungan Universitas Singaperbangsa Karawang belum memiliki cara untuk menentukan bagaimana seorang pegawai berhak mendapatkan Tunjangan Kinerja. Berdasarkan fakta-fakta tersebut akan dibuat sebuah sistem informasi tunjangan kinerja pegawai berbasis website dengan Studi kasus biro kepegawain universitas singaperbangsa karawang. Sistem yang akan dibangun meliputi definisi kriteria, pengolahan data hingga menjadi rekomendasi pegawai terbaik/kenaikan jabatan dan penentuan Tunjangan Kinerja Pegawai. Metodologi yang digunakan yaitu rekayasa perangkat lunak dan menggunakan metode Software Development Life Cycle (SDLC) dengan model waterfall karena sesuai dengan penelitian yang akan dilakukan dengan tahap penggunaan sistem yang relatif singkat. Proses perhitungan dilakukan dengan menggunakan metode fuzzy multiple attribute decision making dengan weighted product karena metode ini menentukan nilai bobot untuk setiap atribut, kemudian dilanjutkan dengan proses perangkingan yang akan menyeleksi alternatif terbaik dari sejumlah alternatif. Sistem yang dibuat dapat memberikan informasi mengenai besaran tunjangan kinerja pegawai dan rekomendasi kenaikan jabatan bagi pegawai . Setelah dilakukan evaluasi user sistem ini mendaptakan tanggapan mudah dimengerti dan mudah dipahami pada setiap menu pada sistem. Melihat dari faktor kebermanfatan sistem ini bermanfaat pada saat akan memberikan tunjangan kinerja kepada pegawai dan pada saat akan menentukan pegawai yang direkondasikan kenaikan jabatan. Perancangan sistem pendukung keputusan rekomendasi pegawai menggunakan fuzzy multiple attribute decision making dilakukan dengan penyelesaian weighted product untuk menghasilkan alternatif setelah dilakukan verifikasi dengan data yang ada mendapatkan akurasi $60 \%$.
\end{abstract}

Kata Kunci: Information System, Decision Support System, Waterfall, FMADM, WP

\section{Abstract}

Universitas Singaperbangsa Karawang does not yet have a system and criteria for assessing the performance of non-P3K employees. Currently the staffing office at the University of Singaperbangsa Karawang does not yet have a way to determine how an employee is entitled to a Performance Allowance. Based on these facts, a website-based employee performance allowance information system will be created with a case study of the staff of the singaperbangsa karawang university. The system to be built includes the definition of criteria, data processing to become the best employee recommendation / promotion and determination of Employee Performance Allowances. The methodology used is software engineering and uses the Software Development Life Cycle (SDLC) method with the waterfall model because it is in accordance with the research that will be carried out with a relatively short stage of system usage. The calculation process is done by using the method of fuzzy multiple attribute decision making with weighted product because this method determines the weight value for each attribute, then proceed with a ranking process that will select the best alternative from a number of alternatives. The system created can provide information about the amount of employee performance benefits and recommendations for promotion for employees. After evaluating the user, this system gets a response that is easy to understand and easy to understand on each menu on the system. Looking at the benefits of this system is useful when it will provide performance allowances to employees and at the time will determine the employees who are reconditioned for promotions. The design of employee recommendation decision support systems using fuzzy multiple attribute decision making is done by completing the weighted product to produce alternatives after verification with the existing data getting $60 \%$ accuracy.

Keywords: Information System, Decision Support System, Waterfall, FMADM, WP

\section{PENDAHULUAN}

Universitas Singaperbangsa Karawang belum memiliki sistem dan kriteria penilain kinerja pegawai non-PNS. Saat ini biro kepegawaian di lingkungan Universitas Singaperbangsa Karawang belum memiliki cara untuk menentukan bagaimana seorang pegawai berhak mendapatkan Tunjangan Kinerja. Tidak adanya mekanisame penilaian Tunjangan Kinerja pegawai mengakibatkan tidak proporsionalnya pemberian tunjangan kepada pegawai. Banyaknya pegawai yang mendapatkan tunjangan tidak sesuai dengan kinerja dan statusnya mengakibatkan kecemburuan di antara pegawai yang mengakibatkan suasana kerja yang kurang baik. Berdasarkan hasil wawancara dengan kepala bagian umum Universitas Singaperbangsa karawang menurutnya nantinya akan ada pemberian tunjangan kinerja untuk pegawai non-P3K dan perlu ada suatu cara untuk memberikan penalian kinerja pegawai untuk menghitung besaran tunjangan. Untuk itu perlu dibuat aplikasi yang bisa membantu proses penilaian kinerja pegawai di Universitas Singaperbangsa Karawang. Hasil dari penilaian pegawai ini nantinya akan berguna untuk pemberian Tunjangan Kinerja Pegawai.

Berdasarkan fakta-fakta tersebut akan dibuat sebuah aplikasi tunjangan kinerja dan rekomendasi pegawai menggunakan menggunakan fuzzy multiple attribute decision making dilakukan dengan penyelesaian weighted product berbasis website dengan Studi kasus biro kepegawain universitas singaperbangsa karawang. Sistem yang 
akan dibangun meliputi definisi kriteria, pengolahan data hingga menjadi rekomendasi pegawai terbaik/kenaikan jabatan dan penentuan Tunjangan Kinerja Pegawai.

\subsection{Objek Penelitian}

\section{METODE PENELITIAN}

Objek penelitian yang akan diteliti adalah Aplikasi penentuan tunjangan kinerja dan rekomendasi Pegawai di Universitas Singaperbangsa Karawang.

\subsection{Metodologi Penelitian}

Metodologi penelitian digunakan adalah Software Development Life Cycle (SDLC) dalam pengembangan menggunakan model Waterfall. Model Waterfall ini metode pengembangannya dilakukan bersama pengguna, sehingga cocok digunakan untuk mendefinisikan kebutuhan pelanggan karena pelanggan sering kali kesulitan menyampaikan kebutuhannya secara detail. Metode pengumpulan data yang digunakan yaitu wawancara dan observasi.

\section{ANALISA DAN PEMBAHASAN}

\subsection{Analisis Kebutuhan Perangkat}

Pengumpulan kebutuhan dalam penelitian ini dilakukan dengan tujuan untuk menganalisa permasalahan dalam penentuan tunjangan kinerja pegawai. Adapun kegiatan yang dihasilkan dalam kegiatan ini adalah analisis sistem berjalan, identifikasi masalah, solusi pemecahan masalah dan kebutuhan sistem.

Dalam melakukan identifikasi kebutuhan sistem, peneliti mendapatkan gambaran kebutuhan sistem seperti berikut:

Tabel 1. Tabel Kebutuhan Sistem

\begin{tabular}{ll}
\hline User & Kebutuhan \\
\hline Admin & 1. Mengelola data pegawai (tambah, edit, hapus). \\
& 2. Mengelola data absensi (tambah, edit) \\
& 3. Mengelola data kinerja (edit) \\
4. Mengelola data integritas (edit) \\
5. Melihat data nominatif dan rekapitulasi. \\
6. Mengelola ketentuan keterlambatan (tambah, edit, hapus). \\
7. Mengelola ketentuan PSW (tambah, edit, hapus). \\
8. Mengelola ketentuan ketidakhadiran (tambah, edit, hapus). \\
9. Mengelola ketentuan tunjangan (tambah, edit, hapus). \\
10. Mengelola Autentifikasi. \\
\hline
\end{tabular}

\subsection{Desain}

Pada tahapan ini dibagi menjadi 2 tahapan yaitu desain UML dan desain interface.

\subsubsection{Desain UML}

Setelah dilakukan identifikasi kebutuhan sistem kemudian di desain dalam bentuk use case diagram, activity diagram, sequence diagram dan class diagram.

\section{a. Use Case Diagram}

Use case diagram digunakan penulis untuk memetakan interaksi langsung antara actor pengguna dengan sistem. 


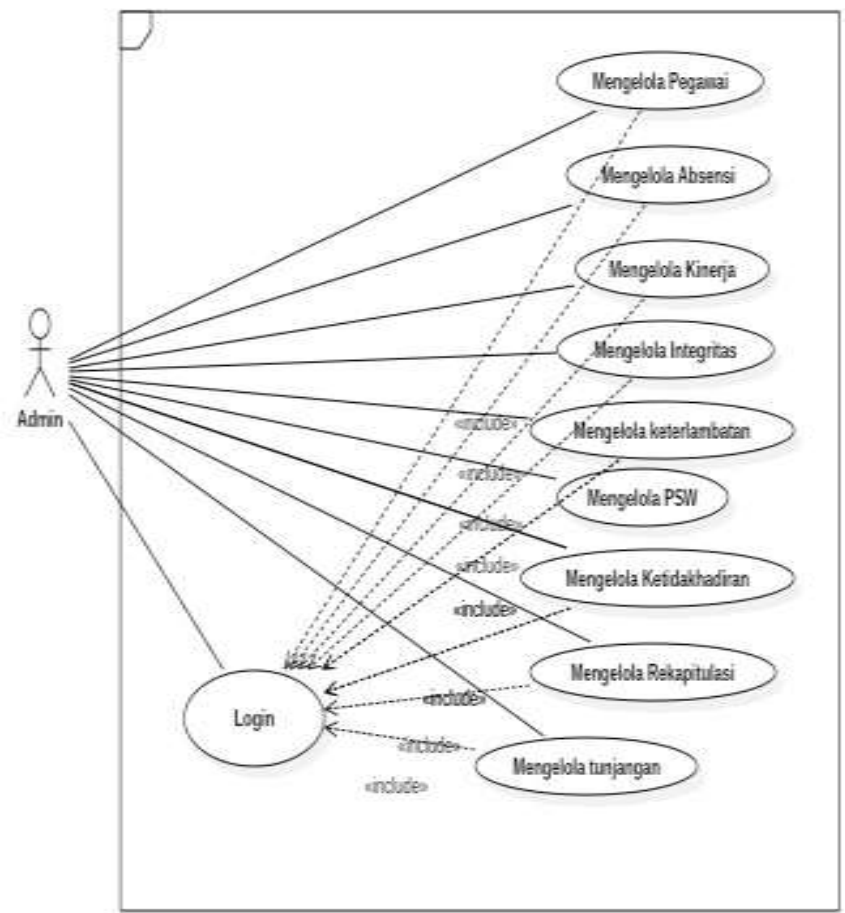

Gambar 1. Use case diagram

\section{b. Activity Diagram}

Berikut ini merupakan activity diagram atau diagram aktifitas yang terdapat pada aplikasi:

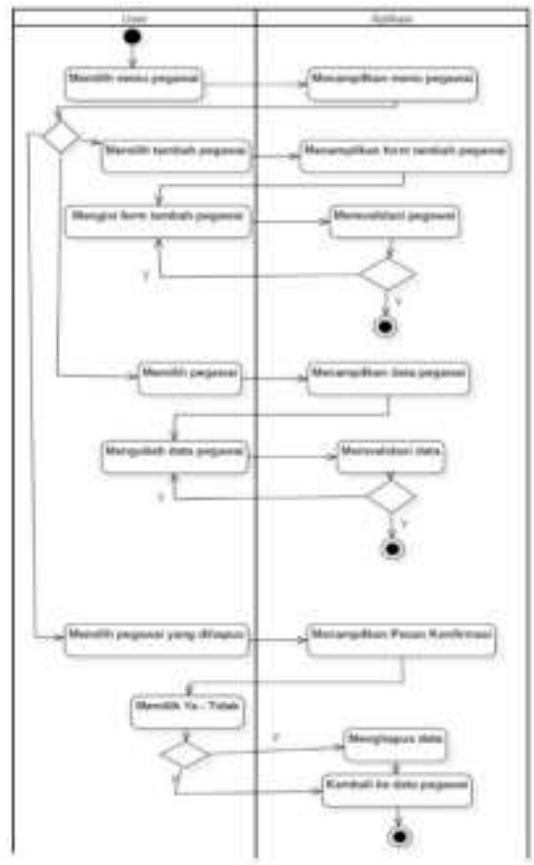

Gambar 2 Activity Diagram Mengelola data pegawai

\section{c. Sequence Diagram}

Berikut ini merupakan sequence diagram yang terdapat pada aplikasi: 
JURNAL MEDIA INFORMATIKA BUDIDARMA, Vol 3, No 3, Juli 2019

ISSN 2614-5278 (media cetak)

ISSN 2548-8368 (media online)

Hal 191-200 | DOI: 10.30865/mib.v3i3.1187

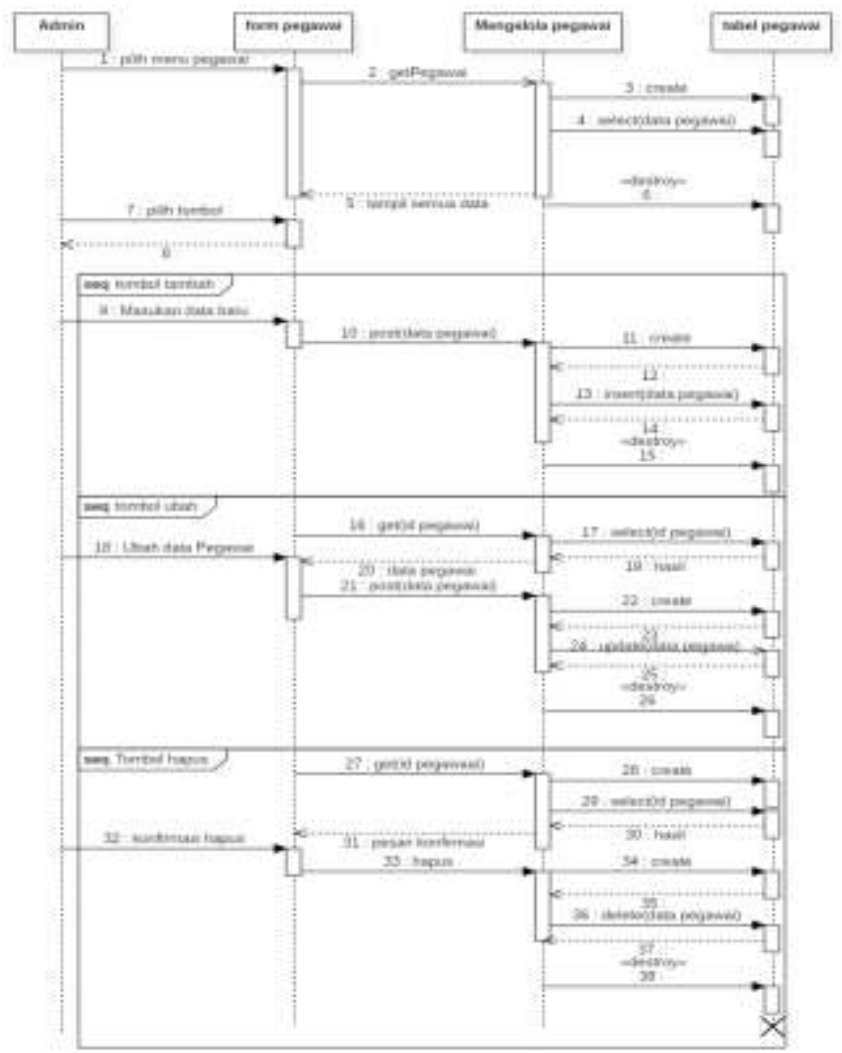

Gambar 3. Sequence diagram mengelola data pegawai

\section{d. Class diagram}

Berikut ini merupakan class diagram yang terdapat pada database aplikasi yang terdapat pada gambar

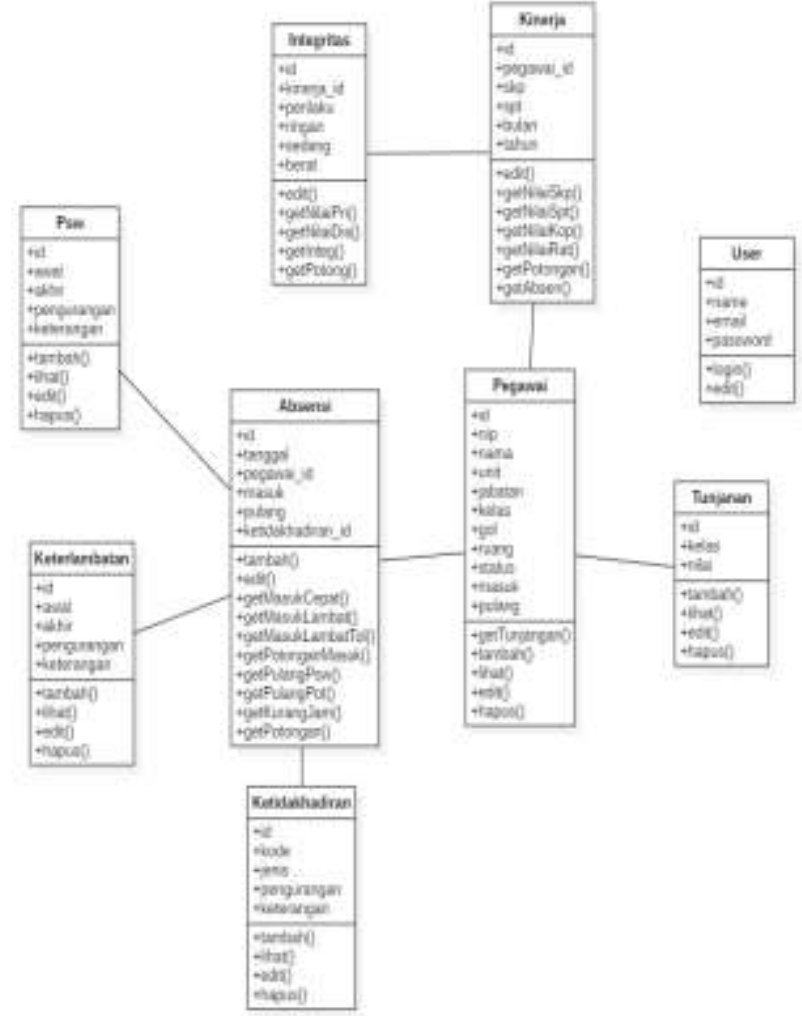

Gambar 4. Class diagram

Aldi Jakaria | http://ejurnal.stmik-budidarma.ac.id/index.php/mib | Page 194 
JURNAL MEDIA INFORMATIKA BUDIDARMA, Vol 3, No 3, Juli 2019

ISSN 2614-5278 (media cetak)

ISSN 2548-8368 (media online)

Hal 191-200 | DOI: 10.30865/mib.v3i3.1187

\subsubsection{Design Interface}

Desain interface merupakan desain antarmuka aplikasi yang akan dibuat. Berikut ini adalah gambaran dari aplikasi ini:

a. .Form menu login

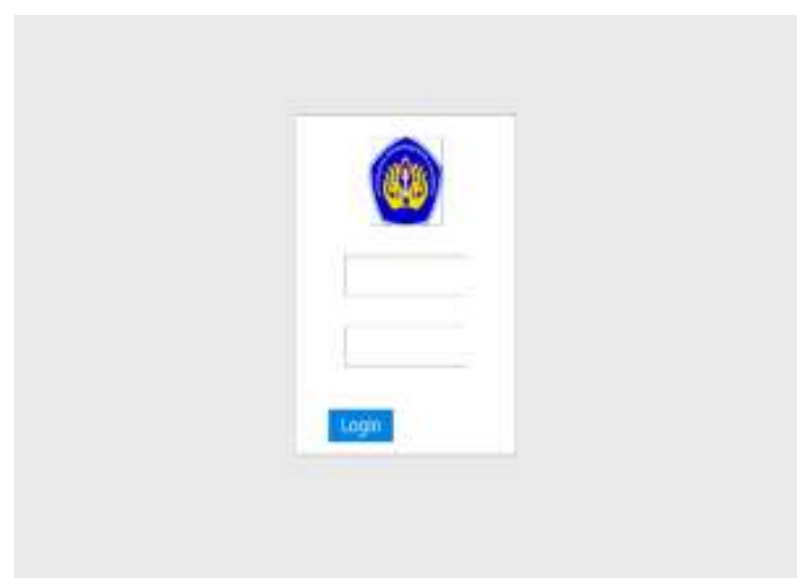

Gambar 5. Rancangan interface login

b. Form menu dashboard

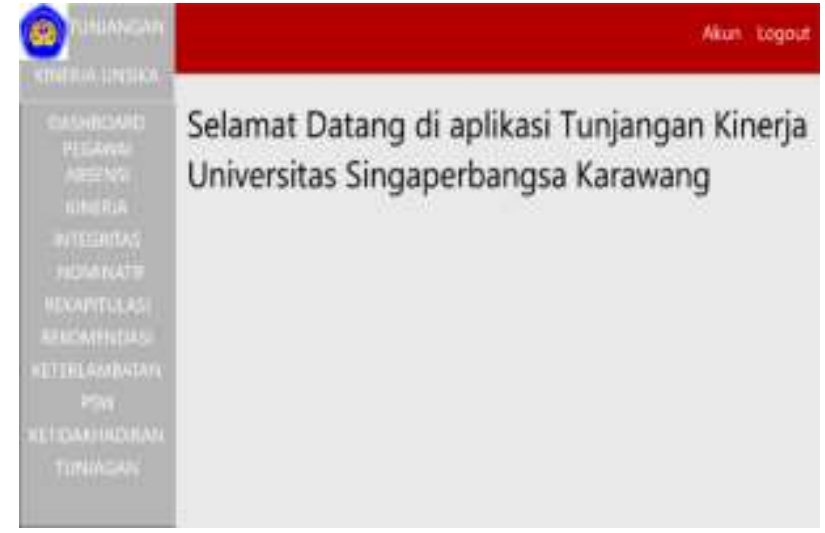

Gambar 6. Rancangan interface menu dashboard

\subsection{Pengkodean Sistem}

Pada tahapan pengkodean sistem terdapat 2 langkah yaitu perhitungan rekomendasi, dan coding.

\subsubsection{Perhitungan Tunjangan kinerja}

Perhitungan tunjangan yang sudah ada yaitu tunjangan kinerja bagi pegawai PNS sudah terdokumntasikan dalam bentuk file microsoft excel, berikut perhitungannya:

a. Tunjangan Kinerja

Besaran Tunjangan kinerja awal berdasarkan kelas jabatan yang sudah ditetapkan Gambar 7 adalah besaran tunjangan kinerja awal yang bagi berdasarakan kelas jabatan dari pegawai,jumlah nilai tunjangan bisa saja berkurang. 


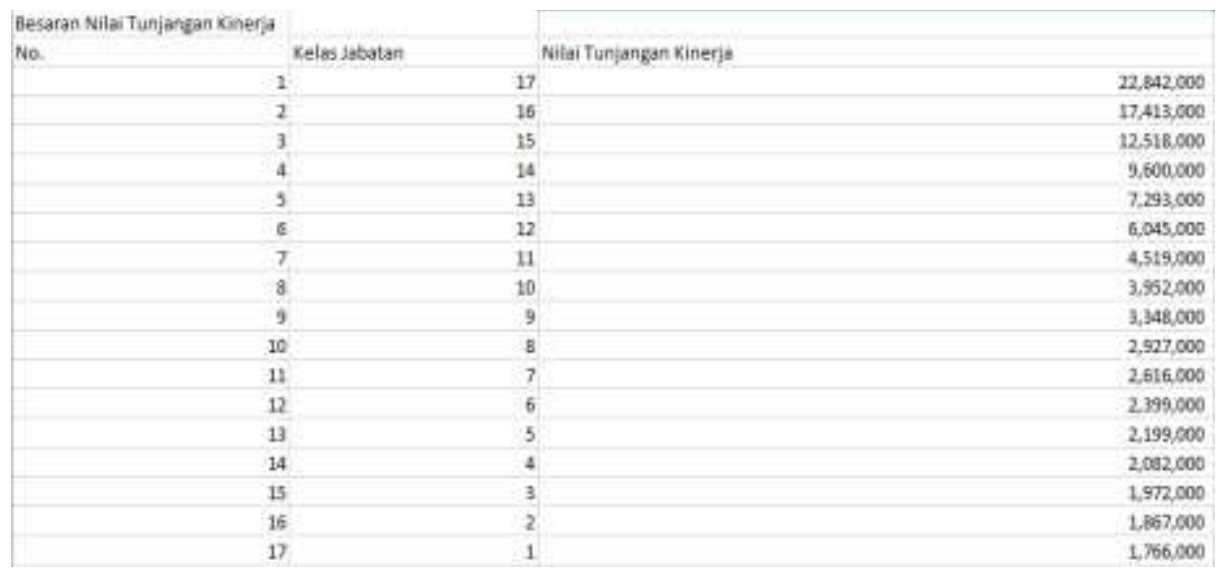

Gambar 7. Nilai Tunjangan kinerja berdasarkan kelas jabatan

b. Absensi

Absensi merupukan salah satu faktor pengurangan dalam menentukan tunjangan kinerja. Absensi dibagi menjadi 3 yaitu keterlambatan, pulang sebelum waktunya (PSW) dan ketidakhadiran. Berikut adalah pengurangan keterlambatan:

\begin{tabular}{c|c|c|}
\hline Keterambatan (menit) & Waktu Kedatangan & Penguranzan (8) \\
\multirow{2}{*}{$0-60$} & & 0 \\
& $07.30-08.30$ & (apabila kekurangan jam kerja diganti pada hari yang sama) \\
\cline { 3 - 3 } & & 0.25 \\
\hline $61-75$ & $08.31-08.45$ & 0.5 \\
\hline $76-90$ & $08.46-09.00$ & 1 \\
\hline $91-105$ & $09.01-09.15$ & 1.5 \\
\hline $106-120$ & $09.16-09.30$ & 2 \\
\hline $121-240$ & $09.31-11.30$ & 2.5 \\
\hline
\end{tabular}

Gambar 8. Pengurangan keterlambatan

Gambar 8 merupakan jumlah pengurangan keterlambatan perhari.

\begin{tabular}{|c|c|}
\hline (menit) & Pengurangin $(5)$ \\
\hline $0-60$ & 0.25 \\
$61-75$ & 0.5 \\
\hline $76-90$ & 1 \\
\hline $91-105$ & 1.5 \\
\hline $106-120$ & 2 \\
\hline $121-240$ & 2.5 \\
\hline
\end{tabular}

Gambar 9. Pengurangan Pulang Sebelum Waktunya (PSW)

Gambar 9 merupakan jumlah pengurangan pulang sebelum waktunya perhari.

\begin{tabular}{|c|c|c|}
\hline No & Jenis Ketidakchadirza & Peagurangan \\
\hline 1. & Cuti Salait & $18 \%$ bari \\
\hline 2. & $\begin{array}{l}\text { Cuti Bersalini, } \\
\text { persalinan pertama } \\
\text { dan kedun }\end{array}$ & $1 \% /$ hari \\
\hline 3. & $\begin{array}{l}\text { Cuti Beraglin untuk } \\
\text { persalinnn leetiga }\end{array}$ & $2 \%$ /thari \\
\hline 4. & $\begin{array}{l}\text { Cuti Bersalin utituk } \\
\text { persalinan loeempat } \\
\text { dan seterusnya }\end{array}$ & $36 /$ hari \\
\hline 5. & $\begin{array}{l}\text { Cuti Karena Alasan } \\
\text { Penting. }\end{array}$ & $32 /$ hari \\
\hline 6. & $\begin{array}{l}\text { Fin (maksimal } 5 \text { hart / } \\
\text { tahnin, Jehilh dari is } \\
\text { hari diperhitungkan } \\
\text { dengan euti tahuman) }\end{array}$ & $3 \% /$ hari \\
\hline 7. & $\begin{array}{l}\text { Tiffak Hadit Tatpa } \\
\text { Keterangan. }\end{array}$ & SSo/hari \\
\hline
\end{tabular}

Gambar 10 Pengurangan berdasarkan ketidakhadiran 
Gambar 10 merupakan jumlah pengurangan pulang sebelum waktunya perhari.Perhitungan absensi dilakukan perhari dan akan diakumulasikan perbulan.

\section{c. Kinerja}

Kinerja adalah salah satu faktor pengurangan Tunjangan kinerja, kinerja dibagi menjadi 3 yaitu Nilai SKP, nilai SPT dan nilai kopertis PTN. Ketiga nilai itu dambil rata-ratanya untuk kemudian di akumulasikan.

\section{d. Integritas}

Integritas adalah salah satu faktor pengurangan yang terdiri dari nilai capaian prilaku, dan hukuman disiplian (ringan, sedang, berat)

\subsubsection{Perhitungan Rekomendasi}

Berdasarkan hasil wawancara kepada kepala biro umum universitas singaperbangsa karawang kriteria penilaian yaitu absesnsi. Kinerja, dan integritas. Data yang didapat berasal dari data bulanan pegawai yang digunakan untuk penentuan tunjangan kinerja. Proses perhitungan dilakukan dengan cara fuzzy multiple attribute decision making. Sebagai sample peneliti menggunakan data nilai tunjangan kinerja pegawai bulan april 2017. Tahapannya sebagai berikut:

Menentukan kriteria-kriteria yang akan dijadikan acuan dalam pengambilan keputusan, yaitu Ci. Pembobotan penilaian dilakukan oleh pemberi keputusan yaitu kepala biro umum. Peneliti telah melakukan observasi dan wawancara kepada kepala biro umum sehingga mendapatkan nilai seperti tabel kriteria dibawah ini.

Tabel 2. Kriteria absensi

\begin{tabular}{lll}
\hline Kategori & Kriteria Absensi & Nilai \\
\hline Character (C1) & $0-19$ & 0 \\
& $20-39$ & 20 \\
& $40-59$ & 40 \\
& $60-79$ & 60 \\
& $80-100$ & 80 \\
\hline
\end{tabular}

Tabel 3. Kriteria Kinerja

\begin{tabular}{lll}
\hline Kategori & Kinerja & Nilai \\
\hline Character (C2) & $0-19$ & 0 \\
& $20-39$ & 20 \\
& $40-59$ & 40 \\
& $60-79$ & 60 \\
& $80-100$ & 80 \\
\hline
\end{tabular}

Tabel 4. Kriteria Integritas

\begin{tabular}{lll}
\hline Kategori & Integritas & Nilai \\
\hline Character (C3) & $0-19$ & 0 \\
& $20-39$ & 20 \\
& $40-59$ & 40 \\
& $60-79$ & 60 \\
& $80-100$ & 80
\end{tabular}

a. Menentukan rating kecocokan setiap alternatif pada setiap kriteria.

Tabel 5. Tabel Rating Kecocokan setiap Alternatif Pada Setiap Kriteria

\begin{tabular}{llll}
\hline \multirow{2}{*}{ Alternatif } & Absensi & $\begin{array}{c}\text { Kriteria } \\
\text { Kinerja }\end{array}$ & Integritas \\
\hline A1 & 80 & 80 & 60 \\
A2 & 80 & 20 & 60 \\
A3 & 80 & 20 & 20 \\
A4 & 80 & 40 & 20 \\
A5 & 80 & 80 & 40
\end{tabular}

Keterangan: A...n = Alternatif

b. Memperbaiki nilai bobot terlebih dahulu dengan cara membagi bobot dengan rata-rata bobot. Dari masingmasing nilai bobot, maka dibuat suatu variabel-variabel dimana dari suatu variabel tersebut akan diubah 
kedalam bilangan fuzzy-nya. Adapun bobot adalah nilai atau tingkat kepentingan relative dari setiap kriteria (Cj) yang diberikan oleh decision maker (kepala bagian umum), dalam hal ini adalah nilai bobot diberikan sebagai berikut : $W=\{w 1, w 2, w 3, \ldots, w n\}$. Dari Bilangan kepentingan bobot $(W)$ yang telah ditentukan dapat dikonversikan kedalam bilangan crips:

$\begin{array}{ll}\text { Sangat Penting (SM) } & =5 \\ \text { Penting (P) } & =4 \\ \text { Cukup Penting (CP) } & =3 \\ \text { Kurang Penting (KP) } & =2 \\ \text { Tidak Penting (TP) } & =1\end{array}$

c. Pengambil keputusan memberikan nilai bobot, berdasarkan tingkat kepentingan masing - masing kriteria yang dibutuhkan. Data bobot ini bersifat dinamis sehingga sesuai kebutuhan pihak terkait, yaitu bobot awal untuk rekomendasi pegawai maka, $\mathrm{W}=(54,4$, $)$, akan diperbaiki sehingga total bobot $\sum \mathrm{Wj}=1$, dengan cara :

$$
\begin{aligned}
& w 1=\frac{5}{3+4+4}=\frac{5}{13}=0,3846 \\
& w 2=\frac{4}{3+4+4}=\frac{4}{13}=0,3076 \\
& w 3=\frac{4}{3+4+4}=\frac{4}{13}=0,3076
\end{aligned}
$$

Dimana: $\mathrm{Wj}=\{0.3846,0.3076,0.3076\}$

d. Nilai seluruh atribut kriteria dipangkatkan dengan bobot yang telah diperbaiki. Bagi sebuah alternatif dengan bobot pangkat positif untuk atribut manfaat dan bobot pangkat negatif pada atribut biaya. Lalu seluruh nilai atribut kriteria dikalikan berdasarkan jumlah kriteria yang dimiliki setiap alternatif untuk mendapatkan nilai vektor $\mathrm{S}$.

$$
\begin{aligned}
& S 1=80^{0,3846} \times 80^{0,3076} \times 60^{0,3076}=73,2229 \\
& S 2=80^{0,3846} \times 60^{0,3076} \times 60^{0,3076}=67,0200 \\
& S 3=80^{0,3846} \times 60^{0,3076} \times 80^{0,3076}=73,2229 \\
& S 4=80^{0,3846} \times 60^{0,3076} \times 80^{0,3076}=73,2229 \\
& S 5=80^{0,3846} \times 80^{0,3076} \times 40^{0,3076}=64,6346
\end{aligned}
$$

e. Hasil perkalian dijumlahkan untuk menghasilkan nilai pada setiap alternatif. Mencari nilai hasil Vektor V dengan melakukan pembagian dengan rata-rata dari nilai hasil setiap perkalian.

$$
\begin{aligned}
V 1 & =\frac{73,2229}{73,2229+67,0200+73,2229+73,2229+64,6346}=\frac{73,2229}{351,3236}=0.2084 \\
V 2 & =\frac{67,0200}{73,2229+67,0200+73,2229+73,2229+64,6346}=\frac{67,0200}{351,3236}=0.1907 \\
V 3 & =\frac{73,2229}{73,2229+67,0200+73,2229+73,2229+64,6346}=\frac{73,229}{351,3236}=0.2084 \\
V 4 & =\frac{73,2229}{73,2229+67,0200+73,2229+73,2229+64,6346}=\frac{73,2229}{351,3236}=0.2084 \\
V 5 & =\frac{64,6346}{73,2229+67,0200+73,2229+73,2229+64,6346}=\frac{73,2229}{351,3236}=0.1839
\end{aligned}
$$

f. Ditemukan urutan nilai hasil terbaik yang akan menjadi keputusan.

\begin{tabular}{ccc}
\multicolumn{3}{c}{ Tabel 6. Hasil Perangkingan (Output) } \\
\hline Alternatif & Nilai S & Rangking \\
\hline A1 & 0,2084 & 1 \\
A3 & 0,2084 & 2 \\
A4 & 0,2084 & 3 \\
A2 & 0,1907 & 4 \\
A5 & 0,1839 & 5 \\
\hline
\end{tabular}

\section{IMPLEMENTASI}

Berikut merupakan hasil implementasi.

a. Halaman Pegawai 


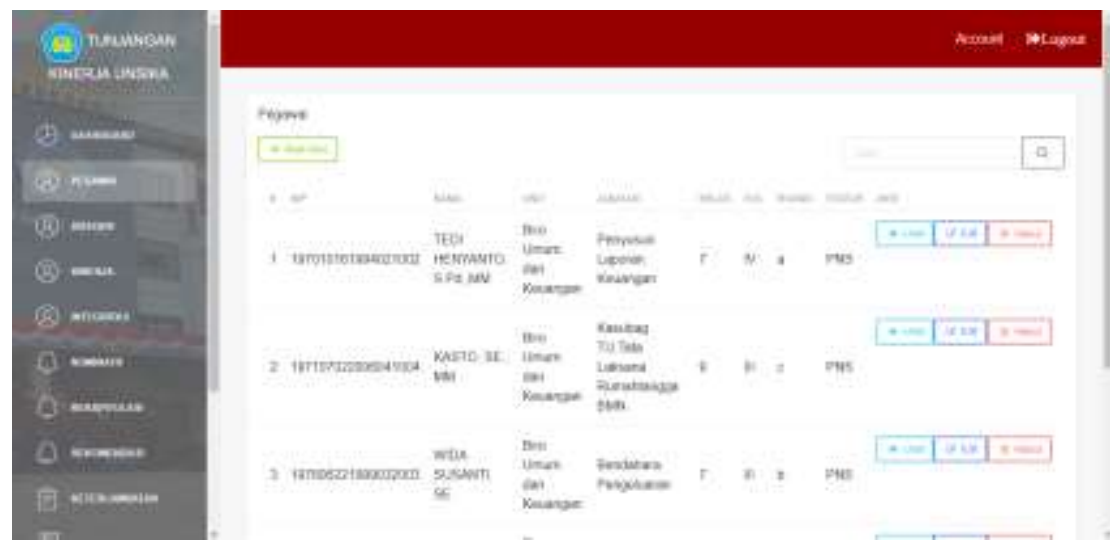

Gambar 11. Halaman Pegawai

b. Halaman Absensi

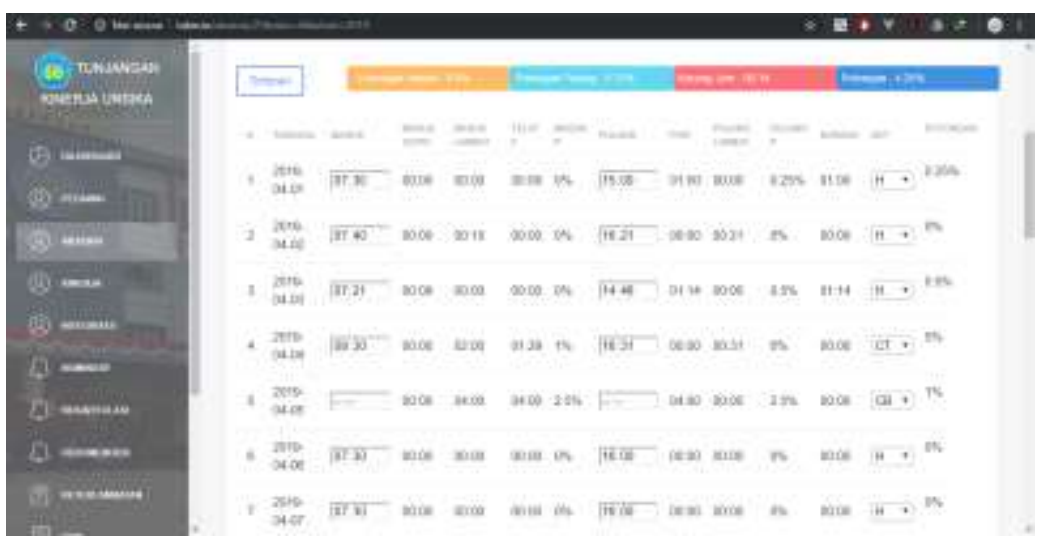

Gambar 12. Halaman Absensi

c. Halaman rekomendasi

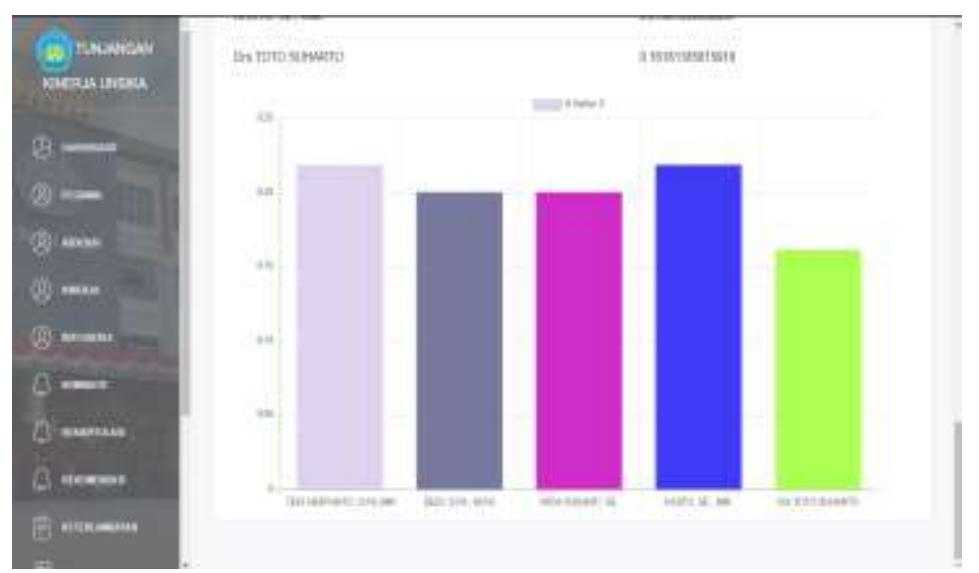

Gambar 13. Halaman Rekomendasi

\section{KESIMPULAN}

Berdasarkan penelitian yang telah dilaksanakan maka terdapat beberapa kesimpulan sebagai berikut:

a. Penentuan kriteria yang digunakan untuk menentukan besaran nilai tunjangan kinerja pegawai yaitu meliputi absensi, kinerja, dan integritas pegawai, dimana masing masing mempunyai perhitungannya masing masing.

b. Perancangan aplikasi yang dibuat dapat memberikan informasi mengenai besaran tunjangan kinerja pegawai dan rekomendasi kenaikan jabatan bagi pegawai menggunakan metode SDLC dengan model waterfall. Setelah dilakukan evaluasi user sistem ini mendaptakan tanggapan mudah dimengerti dan mudah dipahami pada setiap menu pada sistem. Melihat dari faktor kebermanfatan sistem ini bermanfaat pada saat akan memberikan 
tunjangan kinerja kepada pegawai dan pada saat akan menentukan pegawai yang direkondasikan kenaikan jabatan.

c. Implementasi sistem pendukung keputusan rekomendasi pegawai menggunakan fuzzy multiple attribute decision making dilakukan dengan penyelesaian weighted product untuk menghasilkan alternatif setelah dilakukan verifikasi dengan data yang ada mendapatkan akurasi $60 \%$.

Berdasarkan kesimpulan diatas dapat diajukan beberapa saran sebagai referensi untuk penelitian selanjutnya sebagai berikut :

a. Metode perhitungan yang digunakan dapat diganti sesuai rancangan dasar sistem. Hal ini memungkinkan berubahnya hasil yang didapat.

b. Adanya otomatisasi inputasi absensi pegawai menggunakan mesin biometric.

c. Adanya tambahan fitur pada sistem untuk langsung memberitahu pegawai mengenai kehadiran mereka, dan bisa melakukan pengecekan secara langsung.

\section{REFERENCES}

[1] M. I. Utari, "SISTEM INFORMASI KEPEGAWAIAN FAKULTAS," semanTIK, Vol.2, No.1, pp. 187-194, 2016.

[2] E. Tani, "Perancangan Sistem Informasi Kepegawaian PT Sederhana Karya," SENSITEK, pp. 368-372, 2018.

[3] Surianti, "KNOWLEDGE MANAGEMENT SYSTEM PENYAKIT SAWIT,” ILKOM Jurnal Ilmiah Volume 9 Nomor 3 , pp. 361-367, 2017.

[4] A. Sujarwadi, "PERANCANGAN SISTEM PENDUKUNG KEPUTUSAN DENGAN METODE SIMPLE ADDITIVE WEIGHTING (SAW) DALAM PENENTUAN TUNJANGAN KINERJA PEGAWAI PADA KEPOLISIAN RESORT KOTA (POLRESTA) JAMBI.," Jurnal Manajemen Sistem Informasi Vol 1 No. 1, pp. 54-66, 2016.

[5] A. Saputra, "PENGEMBANGAN SISTEM PENDUKUNG KEPUTUSAN PADA," Seminar Informatika Aplikatif Polinema, 2016.

[6] J. R. Sagala, "PENENTUAN, SISTEM PENDUKUNG KEPUTUSAN DALAM,” Jurnal Mantik Penusa Volume 2, No. 2, pp. 84-91, 2018.

[7] S. P. K. D. PENENTUAN, “Jijon Raphita Sagala,” Jurnal Mantik Penusa, pp. 84-91, 2018.

[8] I. Oktafia, “ANALISIS SISTEM AKUNTANSI KOMPENSASI PNS DENGAN MENGGUNAKAN,” Jurnal Administrasi Bisnis (JAB)|Vol. 21 No. 1, pp. 1-7, 2015.

[9] Y. Nyura, "Pembuatan Aplikasi Pembelajaran Bahasa Inggris Pada Handphone dengan J2ME," Jurnal Informatika Mulawarman , pp. $18-27,2016$

[10] M. S. NI'AM, “APLIKASI EVALUASI JABATAN BAGI PEGAWAI NEGERI SIPIL," UNIVERSITAS ISLAM NEGERI MAULANA MALIK IBRAHIM, 2014.

[11] Laravel, "Laravel," 2019. [Online]. Available: laravel.com.

[12] M. Z. Hadi, "SISTEM PENDUKUNG KEPUTUSAN PENENTUAN TUNJANGAN,” Polinema, 2018.

[13] ). M. Fiqry, "SISTEM PENDUKUNG KEPUTUSAN PENENTUAN KINERJA PEGAWAI," Prosiding Seminar Dinamika Informatika 2018 (SENADI 2018), pp. 39-42, 2018.

[14] T. H. BARUS, "Sistem Informasi Penentuan Remunerasi PNS Berdasarkan Peta Jabatan Struktural dan Fungsional," UNIVERSITAS SUMATERA UTARA, 2016.

[15] H. A. Achmad, "SISTEM INFORMASI MANAJEMEN KEPEGAWAIAN," Prosiding SNATIF Ke -4, pp. $405-411,2017$.

[16] Dwi Purnomo, Muslim Alamsyah2, "PERANCANGAN SISTEM PRESENSI KULIAH BERBASIS ANDROID," SENASIF, pp. 10831088, 2018. 